\title{
Elspeth Tilley, White Vanishing: Rethinking Australia's Lost-in-the-Bush Myth
}

\section{Marilyne Brun}

\section{OpenEdition}

1 Journals

Electronic version

URL: https://journals.openedition.org/ces/5760

DOI: $10.4000 /$ ces. 5760

ISSN: 2534-6695

Publisher

SEPC (Société d'études des pays du Commonwealth)

\section{Printed version}

Date of publication: 1 April 2014

Number of pages: 113-114

ISSN: 2270-0633

\section{Electronic reference}

Marilyne Brun, "Elspeth Tilley, White Vanishing: Rethinking Australia's Lost-in-the-Bush Myth",

Commonwealth Essays and Studies [Online], 36.2 | 2014, Online since 15 April 2021, connection on 19

July 2021. URL: http://journals.openedition.org/ces/5760 ; DOI: https://doi.org/10.4000/ces.5760

This text was automatically generated on 19 July 2021.

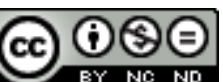

Commonwealth Essays and Studies is licensed under a Licence Creative Commons Attribution - Pas d'Utilisation Commerciale - Pas de Modification 4.0 International. 


\section{Elspeth Tilley, White Vanishing: Rethinking Australia's Lost-in-the-Bush Myth}

Marilyne Brun

\section{REFERENCES}

Elspeth Tilley. White Vanishing: Rethinking Australia's Lost-in-the-Bush Myth. Cross/

Cultures 152. Amsterdam: Rodopi, 2012. 381 p. ISBN (hb): 9789042035959 . €83

1 In White Vanishing: Rethinking Australia's Lost-in-the-Bush Myth, Elspeth Tilley analyses a recurrent motif in non-Indigenous Australian literature, that of narratives of disappearance. White Vanishing seeks to deconstruct the mythic, discursive, and ideological dimensions at work in "lost-in-the-bush" episodes. Tilley points out that those who disappear are "invariably white, like the authors" (9), and therefore proposes an analysis of white disappearance narratives in non-Indigenous Australian literature. She argues for the specificity of Australian "white vanishings" - the physical disappearance of white characters in the bush, whether by disorientation, intention, or abduction - proposing that they are distinctly different from other disappearance narratives such as European lost myths. Tilley argues that the motif is not an innocent or sublime trope in Australian literature, but "a heavily political textual strategy" (14) which symbolically asserts and reinforces settler colonial hegemony.

2 The first chapter provides a detailed review of the literary criticism produced on "lostin-the-bush" tropes. Tilley remarks that the lost-child trope has been the object of much research, but argues that child vanishings should not be separated from other disappearance narratives. The lost-child trope, she contends, is part of a wider motif of white vanishing that constitutes a "strategy of forgetting and displacing the nonwhite" (35). 
3 Tilley's research leads her to identify four main semiotic features for the trope (which are termed "commodities" in the work): white vanishing texts invariably displace Indigenous peoples; although such texts seem to deal with white absence, they in fact assert white presence and authority (what Tilley terms "white presencing"); their treatment of time further reinforces white presence through the use of discourses of progress and the binary opposition of settler and Indigenous time frames; finally, the spatial politics of white vanishing narratives involve a "naturalized colonization of Indigenous space" (53).

4 The concept of naturalization is at the centre of Tilley's argumentation, since she contends that the white vanishing trope as a whole represents a naturalization of Indigenous (physical and psychological) displacement, of settler colonial presence, and of Anglo-Celtic values on "life, love, family, nurturing, prosperity" (247). Tilley points out that Indigenous characters, when they are present in disappearance narratives, are foils in the search for white identity, and only appear in the text at the service of white discourse. Lost-in-the-bush episodes tend to emphasise the dangers of individuality, and as such represent an affirmation of the need for white communal bonding. Yet such episodes also police white subjectivities by forcing, after the disappearance caused by a form of social disequilibrium, white society's "others" -women, workers, and children - to conform to social and patriarchal norms.

While Chapters 2 to 5 present each of the four semiotic commodities individually, Chapter 6 attempts to bring them together and to demonstrate how they intersect and interact in five works by authors Charles Harpur, Carmel Bird, David Malouf, Robert Wainwright, and Tim Winton. White vanishing texts, Tilley concludes, are characterised by a logic of displacement and replacement, since they all "acknowledge Australia as Aboriginal land at the same time as they work to construct white belonging" (320), obsessively retelling disappearance narratives to naturalize settler presence and values in Australia.

6 Tilley uses her extensive knowledge of non-Indigenous Australian literature and postcolonial/settler colonial theory to provide insightful, broad analyses of the trope across genres and periods, which she combines with detailed studies of specific works. One could regret, however, the fact that her analysis remains overwhelmingly based on colonial, rather than contemporary, works. The white vanishing trope was recurrent in colonial literature, but is not particularly representative of motifs in contemporary Australian literature. A precise analysis of the shifts of the trope depending on the genre or period (notably post-Mabo) would have been very valuable. White Vanishing derives from Tilley's PhD thesis, and the style and structure of the book reflect that. A separate list, in the works cited, of the primary works used in her corpus, would have been useful. Despite the limits of the analysis which were pointed at above, and although one could deplore the high price of the book, which will probably limit its distribution to university libraries, it will provide academics and students working on non-Indigenous Australian literature and Australian settler colonialism with a clear demonstration of the insidious nature of settler colonial logics. 